function in children with cystic fibrosis and child control subjects. Pediat. Res. 10: $574(1976)$.

7. Blomfield. J.. Rush, A. R.. and Allars, H. M.: Interreliationships between flow rate. amylase. calcium, sodium, potassitum. and inergatnic phosphate in interval studier of citric ateid stimulated parotid salivat of soung adults. A reh. Oral Biol. (In press.)

8. Blomfield. J., ran Lennep, 1. W., Shorev. C. D.. Malin. A. S.. Dascalu, J.. and

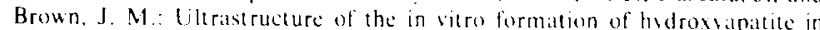
submandibular saliva of children with astic fibrosis. Arch. Orall Biol.. 14:1153 (1974).

9. Boat, T. F.. Wiesman. U. N.. and Pallavicini. J. C . Purification and propertics of the calcium-precipitable protein in submaxillars saliva of nurmal and astic fibrosis subjects Pediat Res, 8.531 (1974).

10. Boursnell, J. (... and Roberts. T. K.: The role of zinc in promoting the opalescence and cold-precipitation of boar seminal plasmat. I. Reprod. Fertil. 36 $91(1974)$

11. Cancro, L. P.. Mones. F., Martin, D. M., and Weater, I. M.: The formation of hydroxyapatite during incubation of saliva. IADR Abst . p. 107 (1970)

12. Chen. P. S.. Toribarat. T. Y.. and Warner. H.: Microdetermination of phosphorus Anal. Chem.. $28: 1756(1956)$.

3. Dawes, $C$.: The secretion of magnesium and calcium in human parotid salliva Caries Res., l: 333 (1967)

14. Dawes. C.: The effects of flow rate and duration of stimulation on the concentrations of protein and the main electrolvtes in human parotid saliwa Arch. Oral Biol.. 14: $277(1969)$

15. Iggstein. M.. and Kreut. F. H.: Vergleichende Untersuchungen zur quantilativen Eiueissbestimmung im Liquor und Fiweissarmen Liosungen. Klin. Wschr., 33: 879 (1955)

16. (jow, B. S.: Analysis of metals in saliva by atomic absorption spectroscops. I Calcium. J. Dent. Res. 44:885 (1965)

17. Gron. P.: The state of calcium and inorganic orthophosphate in human salivat Arch. Oral Biol.. 18: 1365 (1973).

18. (irøn. P.: Saturation of human saliva with calcium phosphates. Arch. Oral Biol. I8: 1385 (1973).

19. Hay, D. I.: The interaction of human parotid salitary proteins with hydroxyapatite. Arch. Oral Biol.. 1s: 1517 (1973).
20. Johansen, P. (i. Anderson, C, M and Hadern, B . Cistic fibrosis of the pancreas. A generalised disturbance of water and electrolste movement in exocrine tissues. Lancet, $i: 455$ (1968)

21. Lowry. O. H., Rosebrough, N. J., Farr, A. L., and Randall, R. J.: Protein measurement with the Folin phenol reigent. I. Biol (hem. 193: 265 (1951).

22. Mckenzic. H. A.: Milk proteins. Advan. Protein (hem.. 22: 55 (1967).

23. Noble. R. W.. and Watugh. D. F.: (asein micelles: formation and structure. Amer. (hem. Soc. J., $8 ?: 2236(1965)$

24. Oakenfull, D. ( $i$.: The eflects of urea ind guanidine hydrochloride on hydrophobic interactions. Proc. Aust. Biochem. Sox. 7: 20 (1974)

25. Oppenheimer. F. Il and Esterly, J R. Observations on cystic fihrosis of the pancreas. V. Developmental changes in the male genital sistem. J. Pediat. 75. $806(1969)$.

26. Roberts. T. K.. and Boursnell, . . C.: The importance of anc in cooling boar semen. J. Reprod. Fertil., 35: 595 (1973).

27. Rule, A. H., Kopito, I.., and Shwachman, H.: Chemical analysis of ejaculates from pattents with esstic fibrosis. Fertil. Steril. $21: 515(1970)$

28. Shackleford. J. M., and Bentlev. H. P.: Carbohydrate histochemistry of the salivary glands and pancreas in cystic fibrosis. I. Histochem. Cytochem., I2. $512(1964)$

29. Termine, J. D., and Eanes, E. D.: (alcium phosphate deposition from halanced salt solutions. Calc. Tiss. Res., 15:81 (1974).

30. Tiscornia, O.. Palasciano, G.. and Sarles. H.: Fiffects of chronic ethanot administration on canine exocrine pancreatic secretion: Further studies. Digestion, 11: 172 (1974)

31. Waugh. D. F., and Noble, R. W. (atsein micelles. Formation and structure. II I Amer. Chem. Soc., 87: 2246 (1965)

32. Wotman, S., Mercadante. J., Mandel. I. D.. (ioldman. R. S.. and Denning. (C. The occurrence of calculus in normal children. children with crstic fibrosis. and children with asthma. J. Periodentol., 44: 278 (1973).

33. This research wats supported in part by The Cystic ribrosis Association of New South Wales and The Clive and Verat Ramaciotli Foundations.

34. Requests for reprints should be addressed to: J Blomfield M Sc Children's Medical Research Foundation, PO Box 61, Camperdown NSW 2050 (Australia).

35. Accepted for publication December 18, 1975.
Colloid crystals cystic fibrosis phosphoprotein

\title{
Colloid and Crystal Formation in Parotid Saliva of Cystic Fibrosis Patients and Non-Cystic Fibrosis Subjects. II. Electron Microscopy and Electrophoresis
}

\author{
HEIEN M. ALLARS, DAVID J. H. COCKAYNE, JEANETTE BLOMFIEL.D, ${ }^{48}$ ANNE R. RUSH. \\ ERNEST W. VAN LENNEP, AND JOHN M. BROWN \\ Childrens Medical Research Foundation and Custic Fibrosis Clinic, Royal Alexandra IIospital for Children, and \\ Electron Microscope Unit and Department of Histology and Embryology, University of Sydney, Sydney,
} New South Wales, Australia

\section{Extract}

Centrifuged pellets of turbid parotid saliva from cystic fibrosis (CF) patients and non- $\left(F\right.$ subjects, obtained from saliva kept at $2^{\circ}$ for $10 \mathrm{~min}$, had the electron microscope appearance of amorphous, round particles, and were thought to be colloidal aggregates of organic material. Drops of turbid saliva, from samples incubated for $2 \mathrm{hr}$ at $2^{\circ}$ or $37^{\circ}$, additionally contained discrete, electron-dense crystals having well defined angular morphology: usually cubic, rectangular, or approximately hexagonal. The inhibitors, urea, guani- dine hydrochloride, and EDTA, resulted in no crystals being observed. Selected area electron diffraction from individual crystals showed predominantly hexagonal, rectangular, or square diffraction patterns. The hexagonal and rectangular patterns could be indexed as coming from hydroxyapatite. A transition from the hexagonal to the rectangular pattern and back to the hexagonal pattern could be obtained from individual crystals tilted in the electron microscope. The square diffraction pattern may be from octacalcium phosphate or brushite.

Polyacrylamide gel disc electrophoresis of the parotid saliva in- 
dicated that the sparingly soluble proteins in the $2^{\circ}$ and $37^{\circ}$ pellets comprised proline-rich proteins and a calcium-precipitable, trichloroacetic acid (TCA)-precipitable phosphoprotein, which fluoresced with amido schwarz and Coomassie brilliant blue G250.

\section{Speculation}

The sparingly soluble colloidal protein droplets and precipitating calcium phosphate crystals are probable causes of parotid duct obstruction and dental calculus in CF patients and heavy calculus formers.

Two types of turbidity have been observed in parotid saliva (1.4) of $\mathrm{CF}$ patients and non-CF subjects. On cooling parotid saliva from $37^{\circ}$ to $2^{\circ}$, a turbidity formed which increased in amount with increasing protein concentration and decreasing temperature, and which consisted predominantly of protein. At $37^{\circ}$, another type of turbidity formed which increased with increasing calcium concentration in the saliva and with time. This turbid material consisted of calcium phosphate and protein. Because of a tendency towards higher calcium and protein concentrations in parotid saliva of children with cystic fibrosis compared with child control subjects $(4,6)$, both $2^{\circ}$ and $37^{\circ}$ turbidity are observed more frequently and to a greater degree in saliva of $C F$ children than control subjects.

In this paper the electron microscopic appearance of both the $2^{\circ}$ and the $37^{\circ}$ turbidity of parotid saliva of both $\mathrm{CF}$ and non-CF subjects is described, and crystalline material is identified using selected area electron diffraction from individual crystals. The protein coming out of solution at both $2^{\circ}$ and $37^{\circ}$ has been investigated by polyacrylamide gel disc electrophoresis, using specially adapted staining techniques to identify characteristics of these sparingly soluble proteins.

\section{MATERIALS AND METHODS}

Citric acid-stimulated parotid saliva was obtained from 13 children with cystic fibrosis (aged 913 years) and 9 non-CF subjects (aged 18-24 years), as previously described (1). Informed consent was obtained from subjects or parents of subjects before saliva collection.

For electron microscopy centrifuged deposits from turbid parotid saliva were obtained from saliva kept for $10 \mathrm{~min}$ at $2^{\circ}$. Pellets were fixed in $2 \%$ glutaraldehyde in $0.1 \mathrm{M}$ cacodylate buffer of $\mathrm{pH}$ 7.2 at room temperature for $1-2 \mathrm{hr}$, then washed in cacodylate buffer, and postfixed in $2 \%$ osmium tetroxide in cacodylate buffer for $1 \mathrm{hr}$ at room temperature. After dehydration in graded ethanol solutions and acetone, the pellets were embedded in Spurr low viscosity resin (43). Thin sections were placed on cellulose acetate and carbon-coated copper grids, and stained in a $5 \%$ aqueous uranyl acetate solution ( $30 \mathrm{~min}$ at room temperature) followed, in some instances, by $8 \%$ lead citrate solution in $0.2 \mathrm{M}$ sodium hydroxide ( $15 \mathrm{~min}$ at room temperature). Sections were examined with a Philips EM 300 microscope.

Drops of turbid saliva from samples kept at $2^{\circ}$ or $37^{\circ}$ for $2 \mathrm{hr}$ were placed directly onto coated grids, blotted dry by tipping with a filter paper, and observed unstained. A grid was gold-coated as a diffraction standard. Grids were examined with a Philips EM 300 electron microscope operating at $60 \mathrm{kV}$, and single-crystal selected area diffraction patterns were obtained from any crystalline material. The camera length, $L$ (i.e., the effective length between the object and the plate in the diffraction mode), was determined using gold as a standard. The crystal lattice spacing, $d$, corresponding to a spacing between diffraction spots, $R$, was then calculated using the equation $d=L \lambda / R$, where $\lambda$ is the electron wave length. The experimental $d$ values were compared with American Society for Testing and Materials (A.S.T.M) file allowed spacings (44) for calcium hydroxyapatite, octacalcium phosphate, brushite, and whitlockite. In order to identify further some diffraction patterns, a goniometer stage with double-tilting holder was used to tilt the crystal, the diffraction pattern being defocussed during tilting as an aid to positioning the crystal. Care was taken to minimize the effect of the beam upon those crystals whose structures were being determined. Diffraction patterns were first quickly examined with low levels of illumination to see whether degradation or changes occurred during analysis

Postmortem tissue (parotid gland) from an 8-year-old girl with cystic fibrosis was fixed in Karnovsky's fixative (22) buffered with $0.1 \mathrm{M}$ cacodylate buffer and postfixed for $1 \mathrm{hr}$ in $2 \%$ osmium tetroxide. Tissue was dehydrated, embedded, sectioned, stained with uranyl acetate and lead citrate, and examined with a Philips EM 300 microscope.

For electrophoretic studies, parotid saliva was left for $10 \mathrm{~min}$ at $2^{\circ}$ or $2 \mathrm{hr}$ at $37^{\circ}$, and the turbid material was separated as centrifuged pellets. Pellets were dissolved in $0.1 \mathrm{M}$ citrate buffer, $\mathrm{pH} 7.2$, to 0.10 original volume. Then $0.2 \mathrm{ml}$ dissolved pellet or uncentrifuged saliva, to which 2 drops of $10 \%$ sucrose had been added, were subjected to polyacrylamide gel disc electrophoresis (13). The samples were layered over a $2.5 \%$ polyacrylamide stacking gel and $7.5 \%$ running gel, and electrophoresis was carried out using borate buffer of $\mathrm{pH} 8.4(30)$

\section{GEI. STAINING}

Amido Schwarz (30). Gels were fixed in $47 \%$ methanol- $47 \%$ water- $6 \%$ acetic acid solution for $30 \mathrm{~min}$ and stained in $0.5 \%$ amido schwarz in $5 \%$ acetic acid for $60 \mathrm{~min}$. Gels were destained for $24.48 \mathrm{hr}$ by continuous flow $5 \%$ acetic acid passing over wool pellets to absorb stain.

Coomassie Brilliant Blue G250 (32). Coomassie brilliant blue G250 dye (45) was made up as a $0.25 \%$ aqueous solution and $15 \mathrm{ml}$ were made up to $100 \mathrm{ml}$ with $3.5 \%$ perchloric acid (PCA). Bands were visible clearly after $45 \mathrm{~min}$ at $37^{\circ}$ and after rinsing with $3.5 \%$ PCA they were allowed to develop overnight in a $1: 10$ dilution of the stain in $3.5 \%$ PCA at room temperature. Any destaining was done in $3.5 \%$ PCA.

Proline-rich Proteins (2). Gels were stained $3060 \mathrm{~min}$ in a $0.5 \%$ solution of 3,3'-dimethoxybenzidine in $5 \%$ acetic acid, containing $0.10 .3 \mathrm{ml}$ hydrogen peroxide $/ 100 \mathrm{ml}$. This staining produced white bands on a brown background which could be partially destained with $2 \%$ ascorbic acid. Brown deposit on gels was removed by washing with water.

Phosphoprotein (2l). Gels were stained $1720 \mathrm{hr}$ at room temperature in a solution containing $2 \%$ acridine orange. $15 \%$ acetic acid, and $1 \%$ lanthanum acetate. A control gel was destained in 15\% acetic acid for 2 days at room temperature while an identical gel was placed in water. Nucleic acid bands were retained stained in both gels, whereas phosphoproteins disappeared in $15 \%$ acetic acid and remained in water.

Trichloroacetic Acid. Gels were immersed in $12.5 \%$ TCA for 1 $\mathrm{hr}$ or more.

Calcium-precipitable Protein (9). Gels were left overnight in 60 $\mathrm{mM}$ calcium chloride solution.

\section{RESULTS}

No differences were observed between turbid saliva from $\mathrm{CF}$ and non-CF subjects, except in that turbidity tended to form more readily and to a greater extent in CF parotid saliva.

\section{ELECTRON MICROSCOPE APPEARANCE OF $2^{\circ}$ AND $37^{\circ}$ PELLETS AND DROPS}

Stained thin sections of pellets obtained after incubation of saliva for $10 \mathrm{~min}$ at $2^{\circ}$ contained amorphous, round particles ranging in size from approximately 0.1 to $20 \mu \mathrm{m}$ (Fig. 1). The particles had no obvious structure or membrane and were thought to be large colloidal aggregates of organic material. When stained with uranyl acetate they had a homogeneous appearance (Fig. $\mid A$ ), but stained additionally with lead citrate, they had a curious, stippled appearance, apparently because of precipitation of lead (Fig. IB). Colloid formed in saliva of both CF and non-CF subjects. 
Drops of turbid saliva, which had been incubated for $2 \mathrm{hr}$ at $2^{\circ}$ or $37^{\circ}$, were placed on coated grids and examined. In salival left at $2^{\circ}$ for $2 \mathrm{hr}$, in addition to colloidal material, small, electron-dense crystals having an angular morphology were sometimes observed in saliva with high calcium concentrations (Fig. 2). In saliva left to incubate at $37^{\circ}$ for $2 \mathrm{hr}$, the predominant crystalline material present in both groups of subjects was in the form of discrete, electron-dense crystals, approximately $0.23 \mu \mathrm{m}$ in diameter with well defined angular morphology, usually cubic, rectangular. or approximately hexagonal (Fig. 3). (rystals often had irregular shapes, and some melted easily in the electron beam from the outside to the center, leaving a hollow shell containing crystallites or layers of crystals (Fig. 3). Crystalline filamentous material, crystals arranged in fern-like patterns, needle-shaped structures. and globular amorphous material were also observed.

Inhibitors $(6 \mathrm{M}$ urea, $6 \mathrm{M}$ guanidine hydrochloride, and $3 \mathrm{mM}$ EDTA), present from the time of collection, resulted in no crystals being observed, but often a dried, pale, unstained, mottled background (Fig. 4) was seen which gave no obvious diffraction spots.

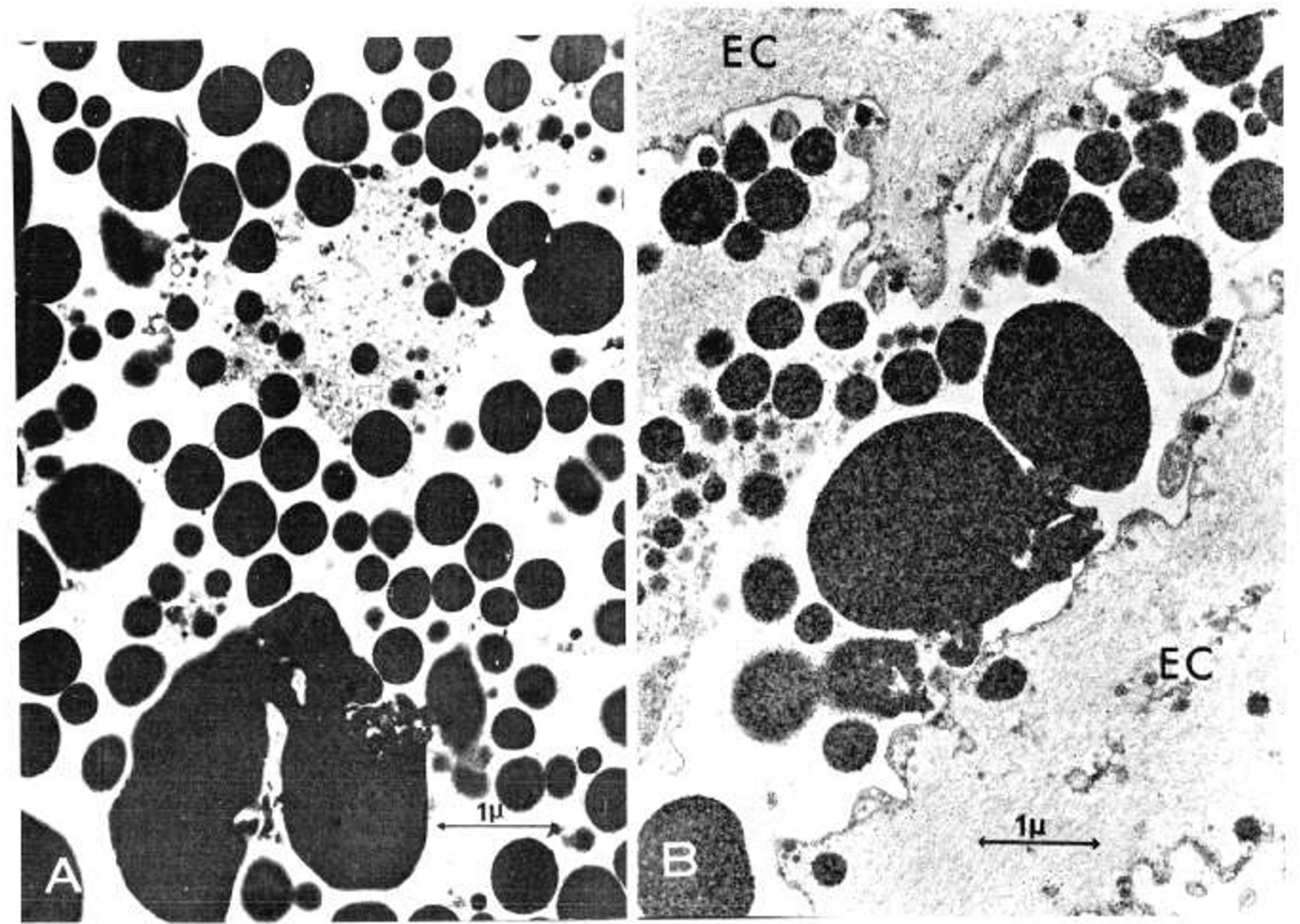

Fig. 1. Colloidal droplets in thin section of centrifuged pellet from turbid parotid saliva. formed after incubation at $2^{\circ}$ for 10 min. 4 , stained by uranyl acetate $(\times 16,000)$. B, stained by uranyl acetate and lead citrate $(\times 16,000)$. EC, epithelial cells.

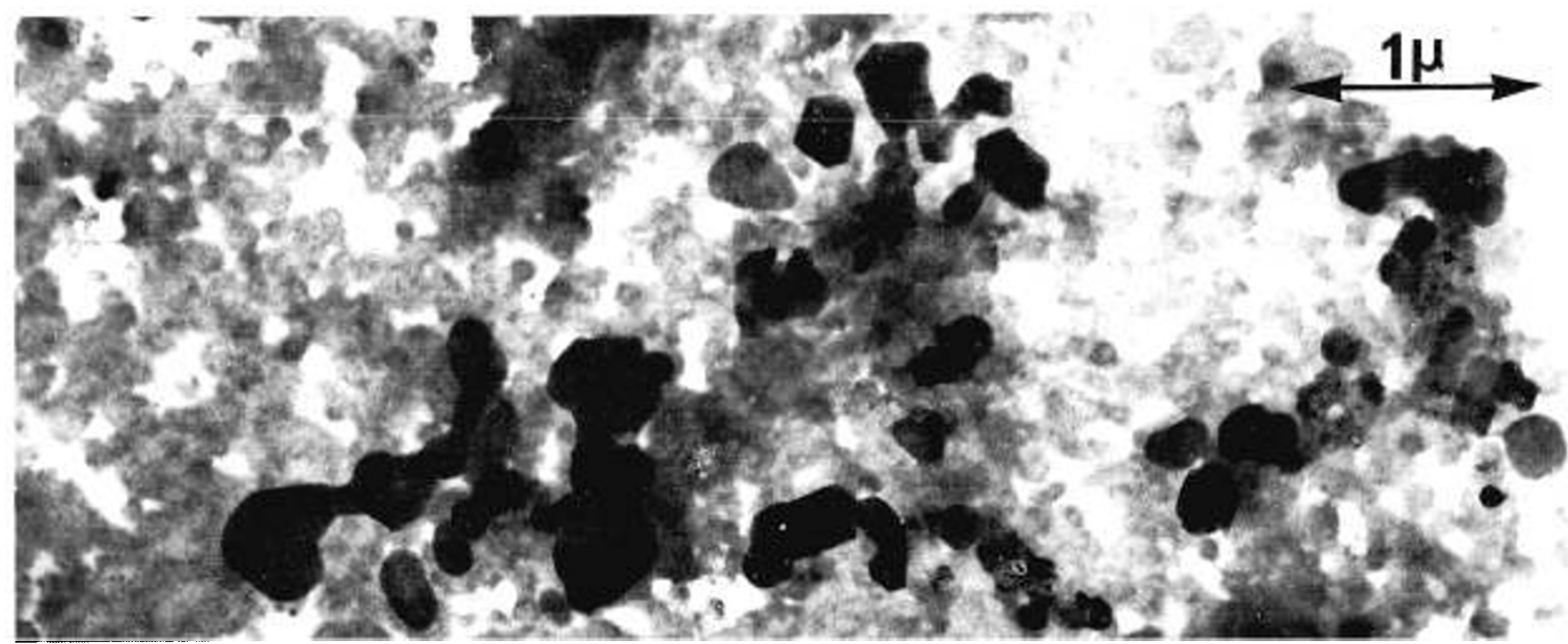

Fig. 2. Amorphous material and clusters of electron-dense crystals with angular morphology in drops of parotid saliva after incubation at $2^{\circ}$ for $2 \mathrm{hr}$ $(\times 24,300$, unstained $)$. 

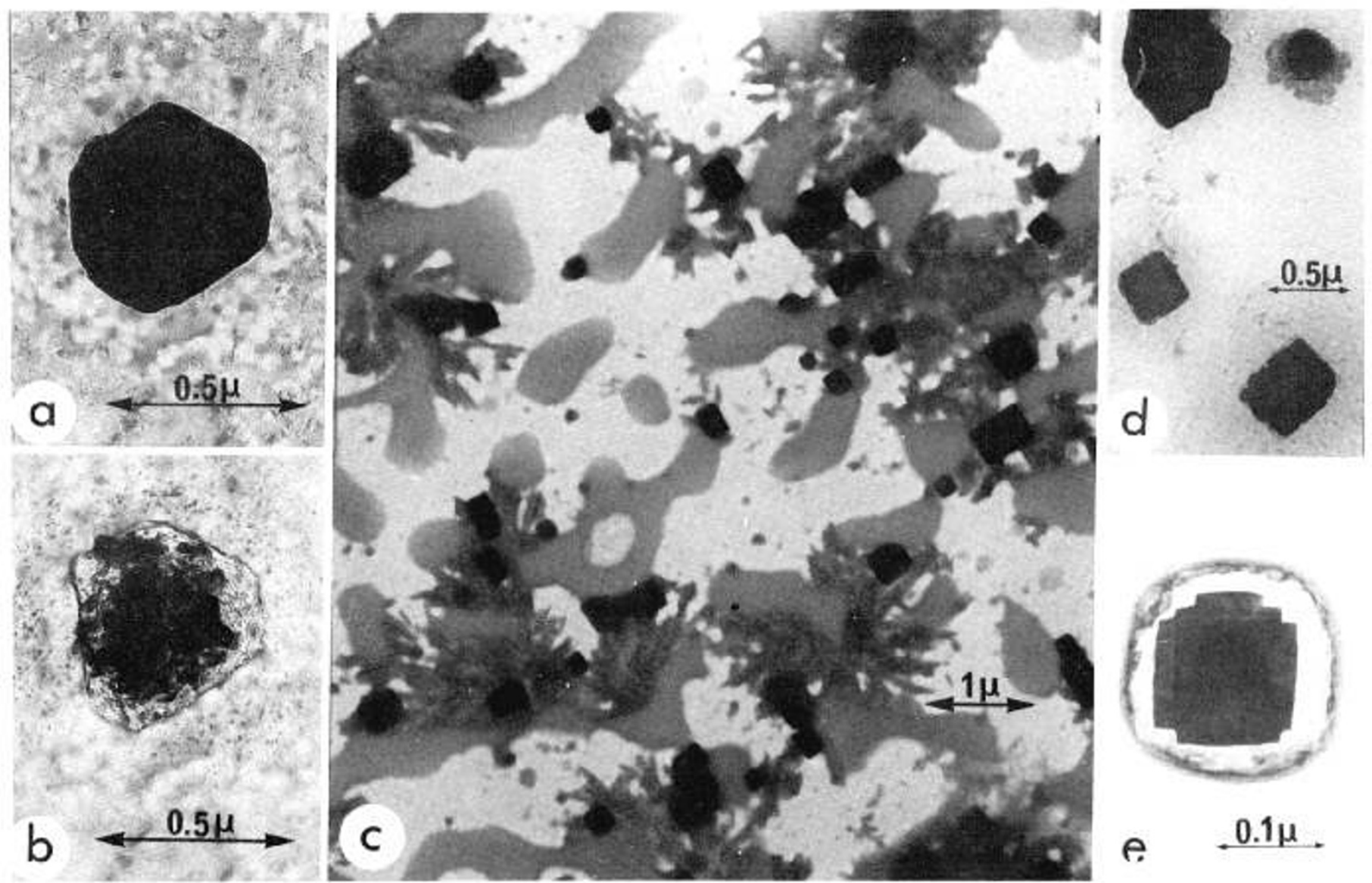

Fig. 3. Colloidal material and electron-dense cubic, rectangular, and hexagonal crystals in drops of parotid saliva kept at $37^{\circ}$ for 2 hr. $b, d$, and $e$ show crystals melting in the electron beam (unstained). $a, \times 52,500 ; b, \times 52,500 ; c, \times 14,300 ; d, \times 21,600 ; e, \times 26,000$.

Table 1. Unit cell dimensions for four major (rystalline calcium phosphates'

\begin{tabular}{|c|c|c|}
\hline Compound & $\mathrm{Ca} / \mathrm{P}$ ratio & Unit cell dimensions \\
\hline $\begin{array}{l}\text { Hydroxyapatite }(10) \\
\quad \mathrm{Ca}_{10}\left(\mathrm{PO}_{4}\right)_{6}(\mathrm{OH})_{2}\end{array}$ & 1.67 & $\begin{array}{l}2 a=18.84, a^{\prime}=9.42, c=6.885 \\
\alpha=\alpha^{\prime}=90^{\circ}, \gamma=120^{\circ}\end{array}$ \\
\hline $\begin{array}{l}\text { Octacalcium phosphate (10) } \\
\qquad \mathrm{Ca}_{4} \mathrm{H}_{\left(\mathrm{PO}_{4}\right)_{3}}\end{array}$ & 1.33 & $\begin{array}{l}\mathrm{a}=19.7, \mathrm{~b}=9.59, \mathrm{c}=6.87 \\
\alpha=\beta=90.7^{\circ}, \gamma=71.8^{\circ}\end{array}$ \\
\hline $\begin{array}{l}\text { Whitlockite (16) } \\
\qquad \mathrm{Ci}_{3}\left(\mathrm{PO}_{4}\right)_{2}\end{array}$ & 1.50 & $\begin{array}{l}\text { Rhomobohed ral cell } \\
\begin{aligned} \mathrm{a} & =\mathrm{b}=\mathrm{c}-13.66 \\
\alpha & =\beta=\gamma-44^{\circ} 66^{1} 2^{\prime} \\
\text { Hexagonal cell } & \\
\mathrm{a} & =10.25, \mathrm{c}=36.9 \\
\alpha & =90^{\circ}, \gamma=120^{\circ}\end{aligned}\end{array}$ \\
\hline $\begin{array}{l}\text { Brushitc (3) } \\
\qquad \mathrm{CaHPO}_{4} \cdot 2 \mathrm{H}_{2} \mathrm{O}\end{array}$ & 1.00 & $\begin{array}{l}a=5.81, b-15.18, c=6.24 \\
\beta=116^{\circ} 25^{\prime}\end{array}$ \\
\hline
\end{tabular}

${ }^{1}$ Measurements of unit cell sides are in Angstroms and angles are in degrees.

ELECTRON DIFFRACTION IDENTIFICATION OF CRYSTALS IN TURBID PAROTID SALIVA

A variety of diffraction patterns was obtained from crystals in drops of turbid parotid saliva which had been incubated at $37^{\circ}$ or $2^{\circ}$. Many of these patterns were observed repeatedly, and attention was focused on three types: hexagonal, rectangular, and square (Figs. 5, 6, and 7). Since calcium and phosphate were deposited in increased amounts from parotid saliva which had become turbid at $37^{\circ}(1)$, and crystals were always abundant in drops of this saliva, the unidentified crystals were thought to be calcium phosphate compounds. Unit cell dimensions for the four major crystalline calcium phosphates have been tabulated (Table 1) and their A.S.T.M. Powder Diffraction File spacings (44) are shown in Table 2 together with calculated lattice spacings from the experimental hexagonal, rectangular, and square patterns.

The $d$ spacings from the hexagonal diffraction pattern were compared with the A.S.T.M. spacings for hydroxyapatite and whitlockite, since these were the only crystalline calcium phosphate compounds of the four considered with $60^{\circ}$ angles in their unit cells. The measured d values for the $110,210,300,310,400$, 222,320 , and 410 reflections of hydroxyapatite corresponded with those observed in hexagonal patterns from parotid saliva crystals 


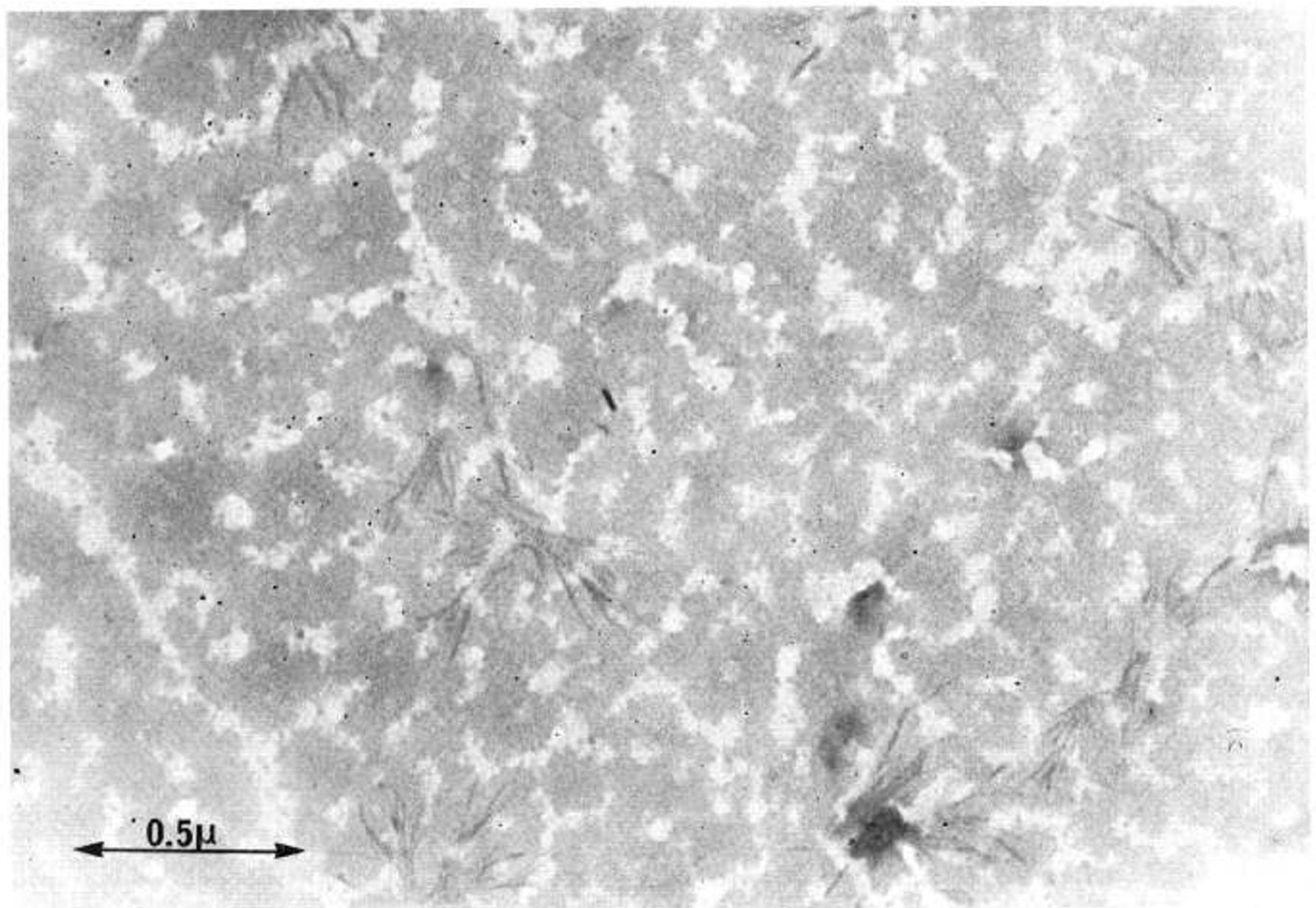

Fig. 4. Pale, mottled material in drops of parotid saliva containing $3 \mathrm{mM}$ EDTA after incubation at $37^{\circ}$ for $2 \mathrm{hr}(\times 60.000$, unstained).

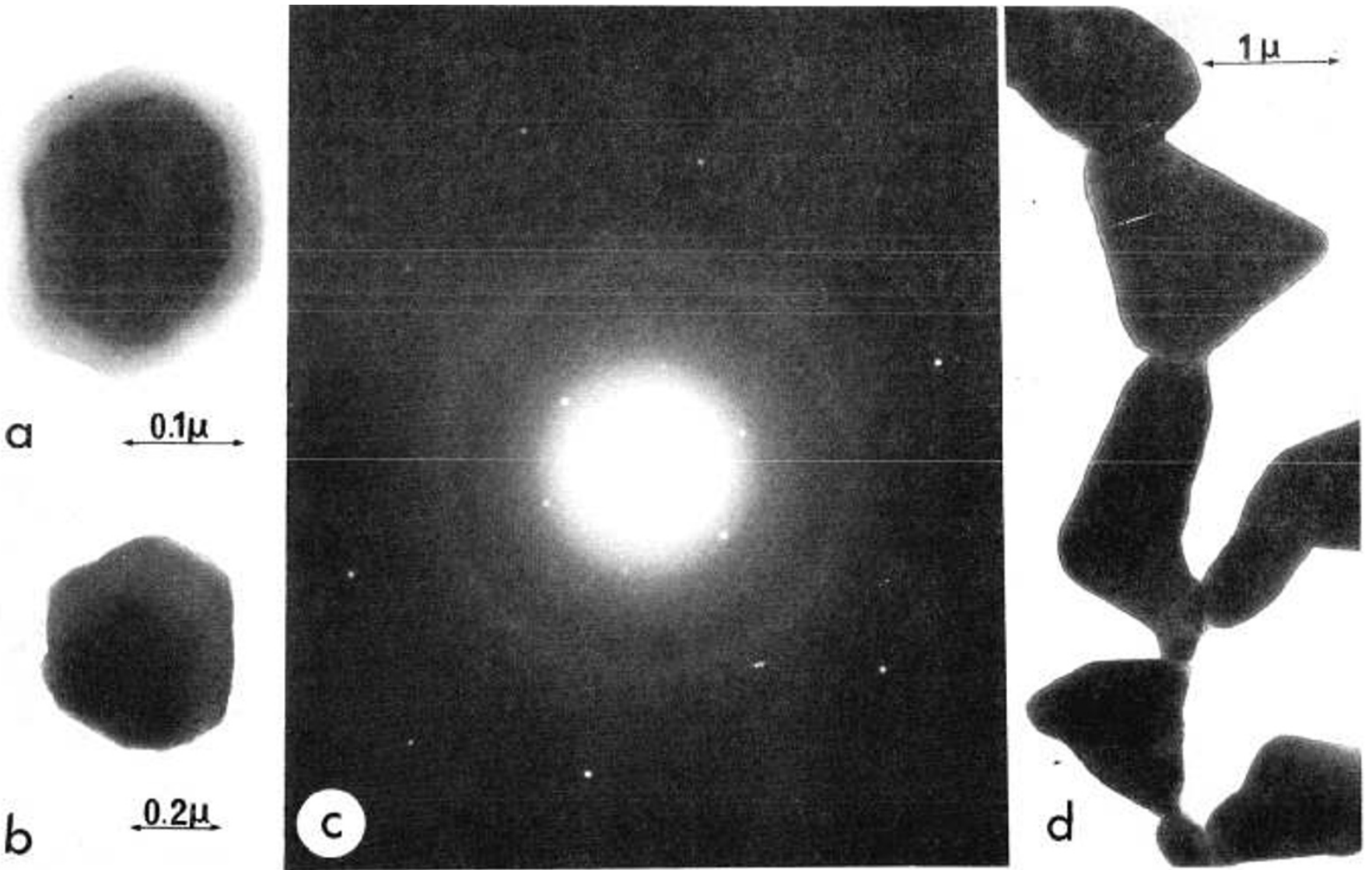

Fig. 5. Hexagonal single-crystal selected area diffraction pattern $(c)$, and crystals $(a, b, d)$ from which hexagonal patterns were obtained (unstained). $a$. $\times 147,000 ; b, \times 52,500 ; d, \times 17,000$. 


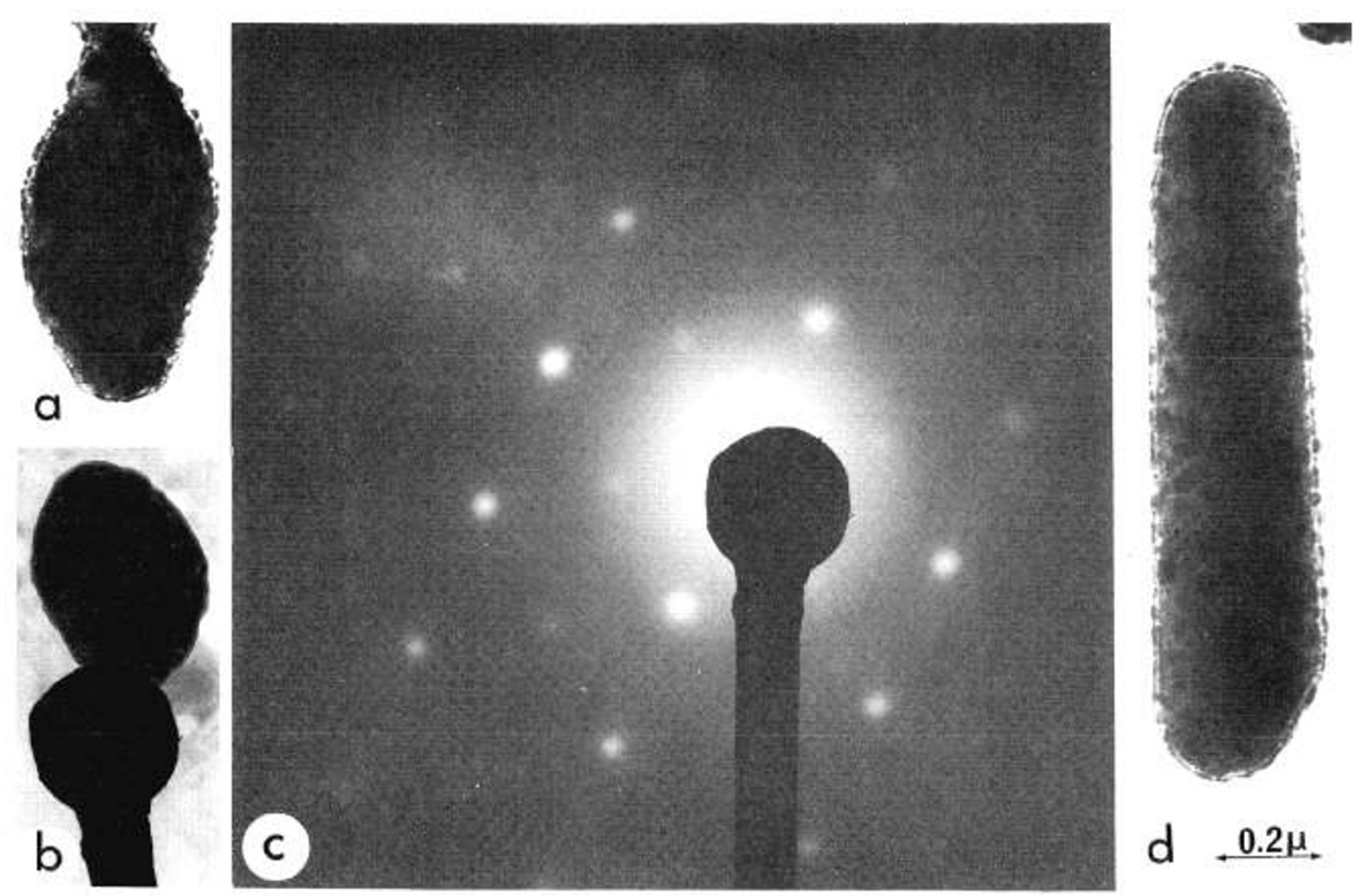

Fig. 6. Rectangular single-crystal selected area diffraction pattern $(c)$, and crystals $(a, b, d)$ from which rectangular patterns were obtained (unstained). $a, \times 65,000 ; b, \times 65,000 ; d, \times 65,000$.

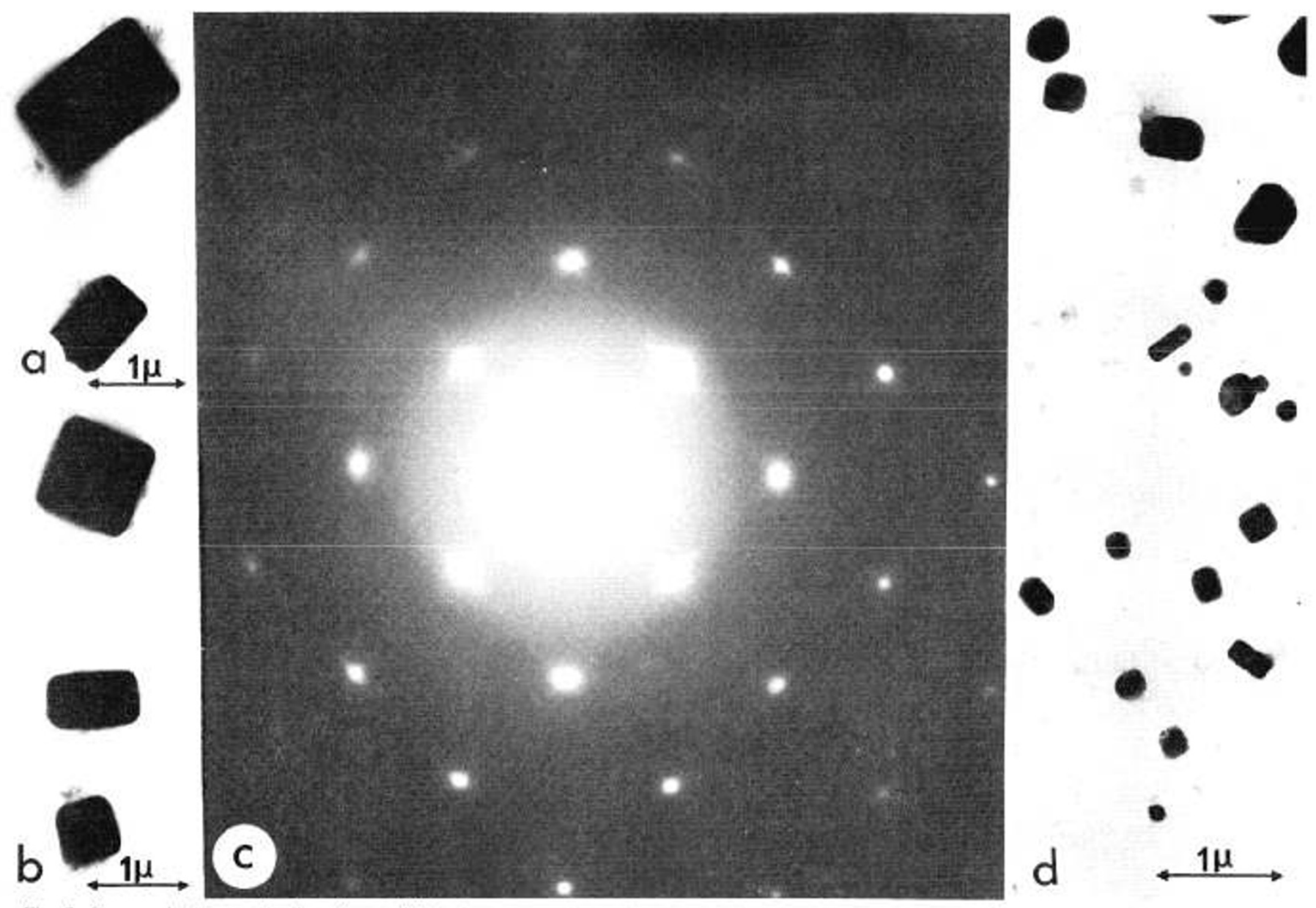

Fig. 7. Syuare singite-crystai selecied area diffraction pattern $(c)$, and crystais $(a, b, a)$ from which square patterns were obtained (unstained). $a, x$ 14,$300 ; b, \times 14,300 ; d, \times 17,000$. 
(Table 2). Smaller d values ( $1.50 \cdots 1.55 \AA$ and $1.29 \quad 1.34 \AA$ ) were also measured and found to correspond to electron diffraction data obtained by Steve-Bocciarelli (36) for hydroxyapatite. The measurements did not correspond as well with the known whitlockite spacings.

The rectangular spacings fitted the hydroxyapatite $\left(\mathrm{d}_{210}\right.$ and $\mathrm{d}_{212}$ ) measurements, and for hydroxyapatite the angle between the 210 and 212 reflections was $90^{\circ}$ as observed in the experimental diffraction patterns. The measured spacings did not fit the A.S.T.M. values for brushite, whitlockite, or octacalcium phosphate as well as they did the hydroxyapatite spacings, and agreement with the geometry of the diffraction patterns and the symmetry of brushite did not seem possible.
Since the hexagonal and rectangular diffraction patterns could be indexed as coming from hydroxyapatite. individual crystals were tilted in the electron microscope to see whether a transition from the hexagonal to the rectangular pattern (and back to the hexagonal pattern to ensure that no change in the crystal had occurred) could be obtained from the one crystal. This was found to be the case, and the relative orientations of the pattern were in accord with the hydroxyatpatite structure.

In analyzing the diffraction patterns, it was noted that certain reflections (e.g., 100, 200) which are not forbidden for the hydroxyapatite structures were not observed (Fig. 5). However these reflections have relatively small scattering factors (A.S.T.M.), and at the same time only small distortions of the

Table 2. Diffraction data for crystals in parotid saliva, and American Society for Testing and Materials (A.S.T.M.) index values for hydroxyapatite $(H A)$, octacalcium phosphate $(O C P)$, brushite $(B)$, and whitlockite $(W)$

\begin{tabular}{|c|c|c|c|c|c|c|c|}
\hline \multicolumn{3}{|c|}{ Observed data } & \multicolumn{5}{|c|}{ A.S.T.M. index of values } \\
\hline \multirow[b]{2}{*}{$\begin{array}{c}\text { Hexagon } \\
\mathrm{d} \AA\end{array}$} & \multirow[b]{2}{*}{$\begin{array}{l}\text { Rectungle } \\
\mathrm{d} \AA\end{array}$} & \multirow[b]{2}{*}{$\begin{array}{l}\text { Square } \\
\mathrm{d} \AA\end{array}$} & \multicolumn{2}{|c|}{$\mathrm{HA}$} & \multirow[b]{2}{*}{$\begin{array}{l}O C P \\
\mathrm{~d} \AA\end{array}$} & \multirow[b]{2}{*}{$\mathrm{d} \AA$} & \multirow[b]{2}{*}{$\begin{array}{c}\mathrm{W} \\
\mathrm{d} \AA\end{array}$} \\
\hline & & & $h k l^{\prime}$ & $\mathrm{d} \AA$ & & & \\
\hline & & & 100 & 8.17 & & & \\
\hline & & & 101 & 5.26 & 18.6 & & \\
\hline \multirow[t]{6}{*}{$4.53-4.72$} & & & 110 & 4.72 & 9.46 & & \\
\hline & & & 200 & 4.07 & 9.07 & & \\
\hline & & & 111 & 3.88 & & 7.57 & \\
\hline & & & 201 & 3.51 & 3.65 & 4.24 & 5.21 \\
\hline & & & 002 & 3.44 & 3.43 & & 3.45 \\
\hline & & & 102 & 3.17 & & & 3.21 \\
\hline \multirow[t]{10}{*}{3.063 .08} & 3.13 & $3.07 \quad 3.12$ & 210 & 3.08 & 3.05 & 3.05 & \\
\hline & & & & & 3.02 & & 3.01 \\
\hline & & & & & 2.79 & & \\
\hline & & & & & 2.95 & 2.93 & 2.88 \\
\hline & & & & & 2.85 & & \\
\hline & & $\begin{array}{lll}2.84 & 2.92\end{array}$ & & & 2.84 & & \\
\hline & & & & & 2.83 & & \\
\hline & & & 211 & 2.81 & & & \\
\hline & & & 112 & 2.78 & 2.77 & & \\
\hline & & & & & 2.75 & & 2.76 \\
\hline \multirow[t]{9}{*}{2.71} & & & 300 & 2.72 & & & \\
\hline & & & & & 2.69 & & \\
\hline & & & & & 2.67 & & \\
\hline & & & & & 2.64 & & \\
\hline & & & 202 & 2.6 .3 & & & \\
\hline & & & & & & 2.62 & \\
\hline & & & & & 2.60 & 2.60 & 2.61 \\
\hline & & & 301 & 2.53 & & & \\
\hline & $2.21 \quad 2.26$ & & 212 & 2.30 & 2.33 & 2.44 & \\
\hline \multirow[t]{5}{*}{$2.21 \quad 2.26$} & & & 310 & 2.26 & & & \\
\hline & & & 221 & 2.23 & & & \\
\hline & & & 311 & 2.15 & & 2.17 & \\
\hline & & & 302 & 2.13 & & & \\
\hline & & & 113 & 2.07 & & & \\
\hline \multirow[t]{2}{*}{1.992 .00} & & & 400 & 2.04 & & & \\
\hline & & & 203 & 2.00 & & & \\
\hline \multirow[t]{2}{*}{1.94} & & & 222 & 1.94 & & & 1.93 \\
\hline & & & 312 & 1.89 & & 1.88 & \\
\hline \multirow[t]{3}{*}{1.81} & & & 320 & 1.87 & 1.86 & 1.82 & \\
\hline & & & 213 & 1.84 & & & \\
\hline & & & 321 & 1.81 & & & \\
\hline \multirow[t]{3}{*}{1.74} & & & 410 & 1.78 & & & \\
\hline & & & $402\}$ & 1.75 & & & \\
\hline & & & $\begin{array}{l}403\} \\
004\end{array}$ & $1 . \%$ & & & \\
\hline $1.50 \quad 1.55$ & & & $\left.\begin{array}{l}0,4 \\
41\end{array}\right\}$ & 1.72 & & & 1.73 \\
\hline $1.29 \quad 1.33$ & & & & & & & \\
\hline
\end{tabular}

'Miller indices of the reflections listed. 
(8

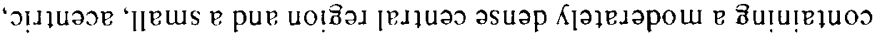

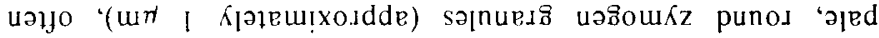

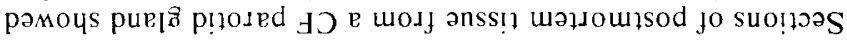

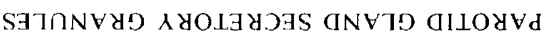

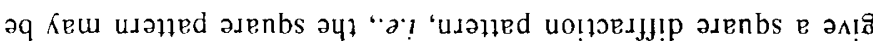

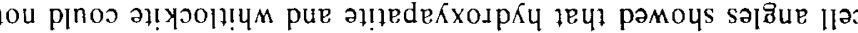

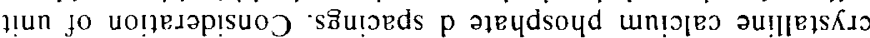

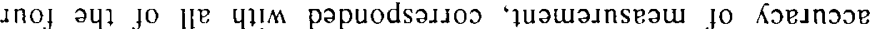

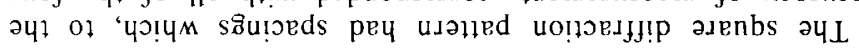

uәр

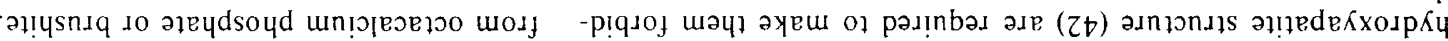

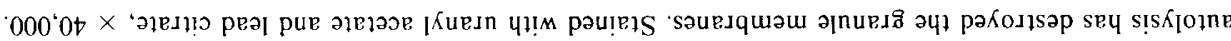

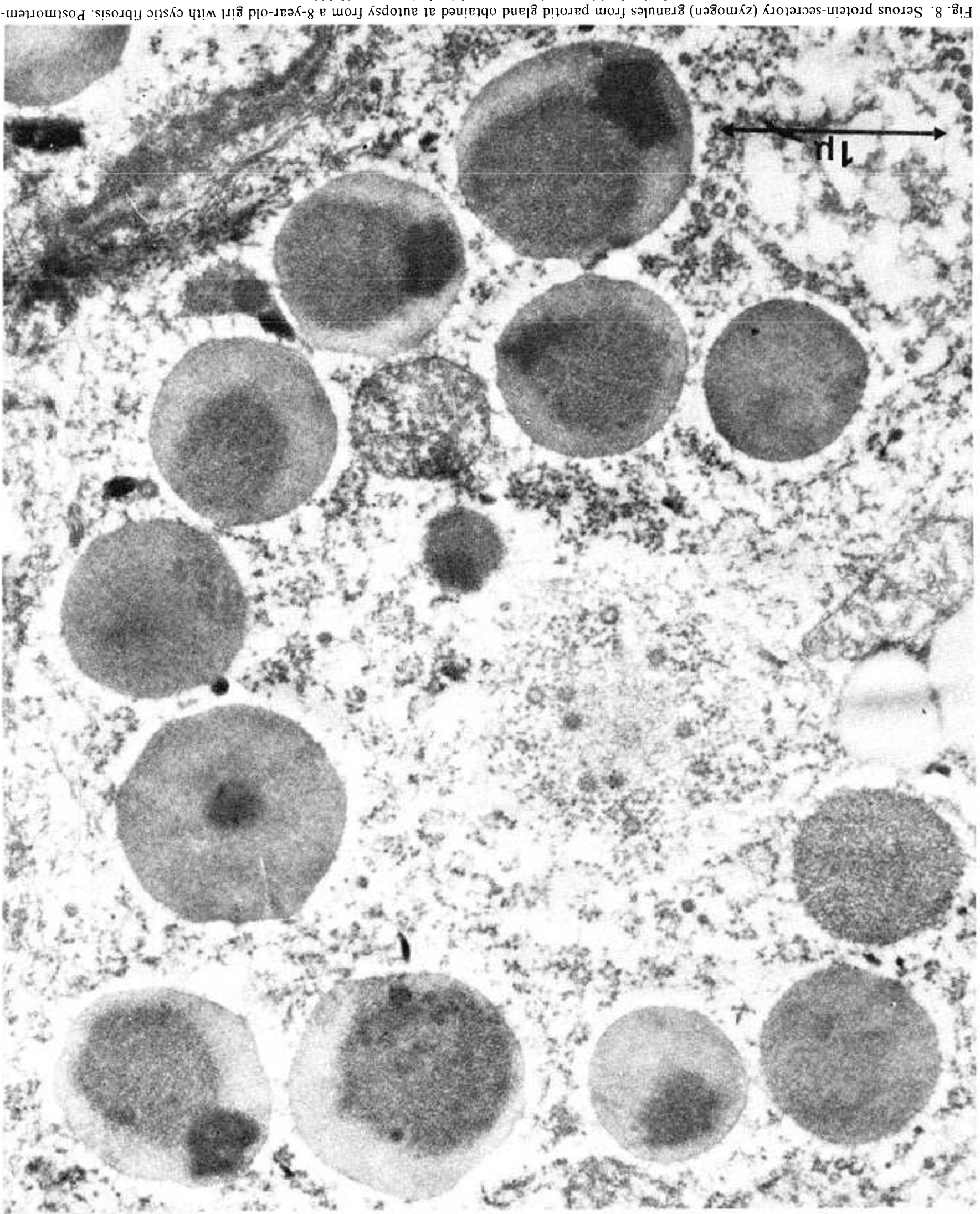

165

II VAITVS AJ NI STVISAYJ GNV SAIOTJOJ 


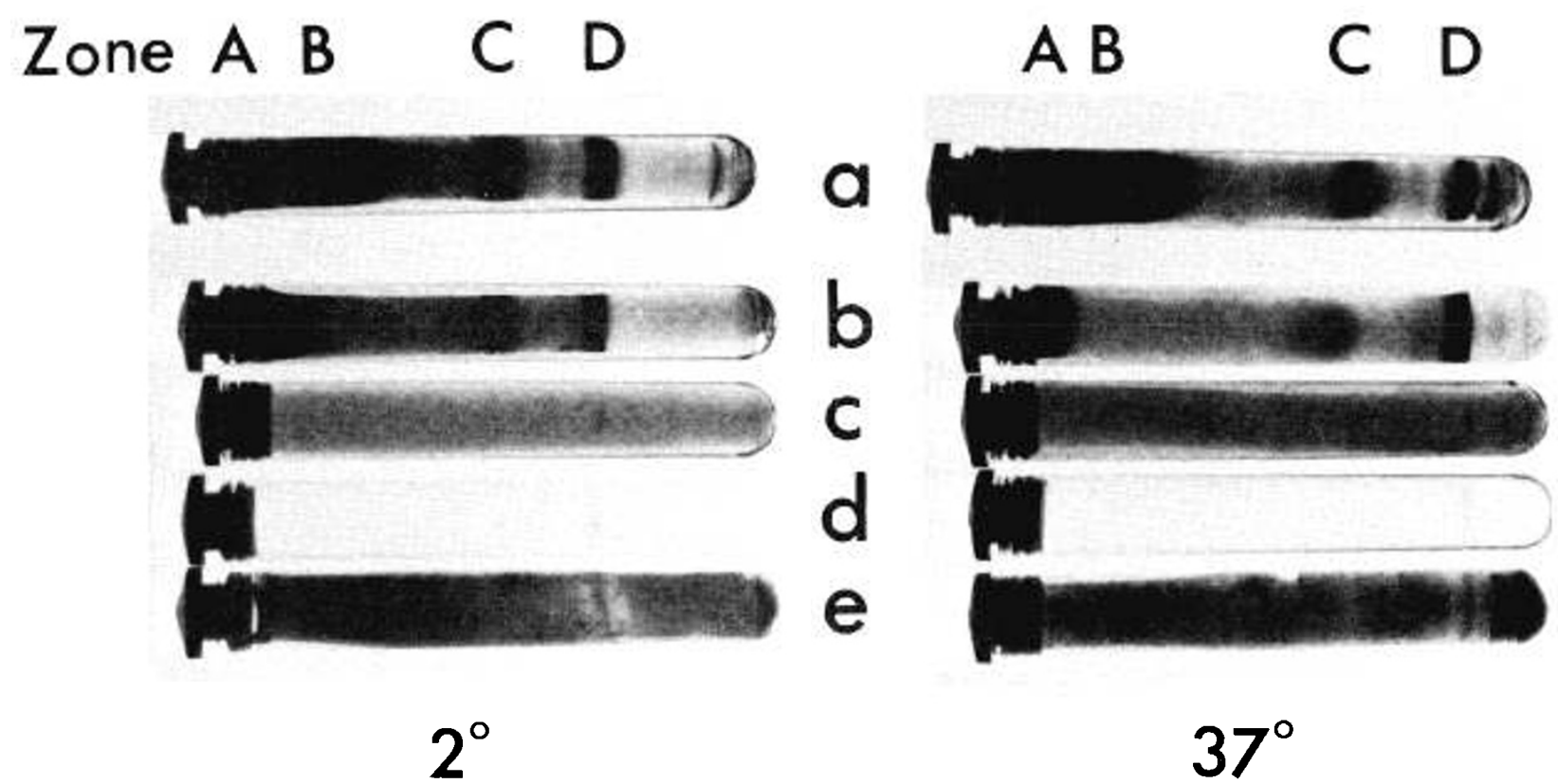

Fig. 9. Polyacrylamide gel disc electrophoresis of uncentrifuged parotid saliva (a) and centrifuged pellets $(b-e)$, incubated at $2^{\circ}$ for 10 min and $37^{\circ}$ for 2 $\mathrm{hr}$, from a child with cystic fibrosis. $a, b$ : Coomassie brilliant blue $\mathrm{G} 250 ; c:$ acridine orange stain for phosphoprotein, $d$ : trichloroacetic acid precipitation: $e$ : proline-rich protein stain. Zones $A, B, C$, and $D$ are indicated.

\section{ELECTROPHORESIS OF PAROTID SALIVA PROTEINS}

Polyacrylamide gel disc electrophoresis of parotid saliva indicated four major zones of proteins with similar motility: $(A)$ a slow-moving zone near the origin, $(B)$ the amylase region, $(C)$ which contains component $I I$ and proline-rich proteins $I$ and $I I$, and $(D)$ comprising component I and proline-rich proteins $I I I$ and IV (nomenclature of Hay (18)). (Fig. $9 a$ ).

Special staining techniques were applied to gels of centrifuged pellets containing the proteins which had separated out of solution after $10 \mathrm{~min}$ at $2^{\circ}\left(2^{\circ}\right.$ pellet $)$ or after $2 \mathrm{hr}$ at $37^{\circ}\left(37^{\circ}\right.$ pellet $)$. The sparingly soluble proteins from both the $2^{\circ}$ and $37^{\circ}$ pellets were found in zones $C$ and $D$, and sometimes in the slow moving zone $A$; the amylase isoenzymes of zone $B$ remained in solution in the turbid saliva (Fig. $9 b$ ). Zone $D$ proteins showed a white fluorescence by reflected light when stained with amido schwarz, and a pink fluorescence when stained with Coomassie brilliant blue G250. Insoluble zone $D$ proteins from both $2^{\circ}$ and $37^{\circ}$ pellets contained a phosphoprotein which was identified by the acridine orange-acetic acid-lanthanum chloride staining method of Kamiya and Okuyama (21) (Fig. 9c), the band disappearing in acetic acid. This phosphoprotein was precipitated as a white, opaque band in the gel by trichloroacetic acid (Fig. 9d). The phosphoprotein also formed a white band when gels were immersed overnight in $60 \mathrm{mM}$ calcium chloride (not shown). The insoluble proteins gave positive reactions to the proline-rich protein stain of Azen and Oppenheim (2) in zones $C$ and $D$ for both $2^{\circ}$ and $37^{\circ}$ incubated pellets (Fig. 9e).

\section{DISCUSSION}

Electron microscope studies have proved to be of value in elucidating the nature of turbid material which forms at $2^{\circ}$ and at $37^{\circ}$ in parotid saliva of cystic fibrosis patients, and to a lesser extent in non-CF subjects. No qualitative differences have been observed between $\mathrm{CF}$ and non-CF saliva deposits.

\section{COLLOID FORMATION}

The round, amorphous, particulate nature of the material formed at $2^{\circ}$ suggested the formation of colloidal aggregates. The particle size $(0.10-20 \mu \mathrm{m})$ was much greater than that of milk micelles $(0.04-0.30 \mu \mathrm{m})$, which have a stabilized structure $(26,28$, 40 ), probably limiting their size. Chemical assays (1) indicated that the colloid consisted of protein and small amounts of calcium and phosphate, with the latter probably being bound specifically to the protein. Colloid formation in parotid saliva was found to be a temperature-sensitive equilibrium process (1), and it seemed likely that colloidal aggregates could coalesce because of close approach in the centrifuged pellet giving the large size range of particles. The protein secretory granules in the parotid gland were small in comparison (approximately $\mathrm{l} \mu \mathrm{m}$ ). The parotid saliva colddependent turbidity was therefore different from CF submandibular saliva turbidity, which contained particles resembling, in size and electron density, undissolved inclusion bodies of serous secretory granules (spherules) (5). The parotid saliva was initially clear, indicating that zymogen granule contents were dissolved on release but formed colloidal aggregates on cooling.

\section{CRYSTAL. FORMATION}

Saliva with increased calcium concent rations formed crystals at temperatures from $2^{\circ}$ to $37^{\circ}$ but most rapidly at $37^{\circ}$ (1). The electron microscopic appearance of most crystals, small, dense, often cubic or with angular morphology (1.20-3.0 $\mu \mathrm{m}$ diameter $)$, was different from the usual descriptions of hydroxyapatite crystals.

Hydroxyapatite is usually thought to form fine needle-like crystals (23), often in "stellate clusters" (II) and to have a $\mathrm{Ca} / \mathrm{P}$ ratio of 1.67 . as observed in cystic fibrosis submandibular salliva $(5$, $7,8,39)$. Hexagonal crystals have been observed in developing tooth enamel (29). Thin platelike "blades" (up to $250 \mu \mathrm{m}$ long) have been associated with the morphology of octacalcium phosphate (10). Füredi-Milhofer et al. (17) described platelike crystallites (identified as octacalcium phosphate), forming at $25^{\circ}$, and microcrystalline agglomerates (identified as calcium-deficient hydroxyapatite), forming at $37^{\circ}$, in mixtures of calcium chloride and sodium phosphate solutions at similar concentrations to those found in parotid saliva. However, Schroeder (34), using electron diffraction, showed that needle-like, ribbon-like, and platelike crystals found in dental calculus had reflections corresponding to hydroxyapatite spacing. It was also noted that since the average $\mathrm{Ca} / \mathrm{P}$ ratio $(0.97 \pm 0.34)$ in our preparations was considerably lower than the pure hydroxyapatite ratio of 1.67 , there might be present amorphous calcium phosphate precursor to hydroxyapatite $(14,37,38)$. The $\mathrm{Ca} / \mathrm{P}$ ratio may also be lower than 1.67 in the actual crystals because of calcium-deficient apatite formation as described by Brown et al. (11). Calcium-deficient apatites were 
often considered to have diffraction spacings similar to hydroxyapatite (31). Brown et al. (11) discussed the formation of platelike crystals containing central "scalar crystallites" of octacalcium phosphate which became the seeds for a direct precipitation of hydroxyapatite, and Francis and Webb (15) discussed the possibility of "sandwich-like crystallites of DCPD-HA-DCPD-HA" where DCPD (dicalcium phosphate dihydrate or brushite) was the precursor template for hydroxyapatite ( $\mathrm{HA}$ ) formation. Either of these structures resulted in lowered $\mathrm{Ca} / \mathrm{P}$ ratio for crystals giving hydroxyapatite diffraction patterns. Cubic crystals were also described by Meyer et al. (27) in a scanning electron microscope study of hydroxyapatite formation (in the presence of potassium and chloride ions). The crystals were cubic only during the initial period of rapid epitaxial growth.

Hence the crystalline material formed at $37^{\circ}$ in parotid saliva with increased calcium levels consisted of hydroxyapatite and of unidentified crystals which gave a square diffraction pattern. The low $\mathrm{Ca} / \mathrm{P}$ ratio of pellets suggested the presence of amorphous calcium phosphate and chemical studies indicated protein binding to the insoluble calcium phosphate complexes (1). Similar formation of hydroxyapatite in saliva has been noted in CF submandibular saliva after it stands at room temperature for $2 \mathrm{hr}(5,7,39)$, in whole saliva of heavy calculus formers after $20 \mathrm{hr}$ of incubation at $37^{\circ}(12)$, and in submandibuiar saliva of normal individuals on standing (24).

\section{ELECTROPHORESIS OF PROTEINS}

Sparingly soluble parotid saliva proteins from both $2^{\circ}$ and $37^{\circ}$ pellets have been identified electrophoretically as proline-rich proteins and a calcium-precipitable phosphoprotein. Although not yet proven, it seems probable that this phosphoprotein is identical with the tyrosine-rich acidic peptide (designated component $I$ by Hay (18, 19)), which has a similar electrophoretic mobility. Component $I$ is preferentially adsorbed from parotid saliva by hydroxyapatite and by ground tooth enamel, and may play a role in the formation of the acquired pellicle and plaque on teeth (18, 19). From the studies of Mayo and Carlson (25) it would appear that, although a phosphoprotein of identical mobility (designated PP7) is found in both parotid and submandibular saliva, the major calcium-precipitable phosphoprotein of the submandibular saliva is a faster moving band (designated PP4). In the turbid submandibular saliva of cystic fibrosis children, it is this calcium-precipitable phosphoprotein (CaPP, PP4) which is the predominant insoluble protein $(5,9)$.

\section{POSSIBLE CIIINICAL SIGNIFICANCE}

The insoluble calcium-phosphate-protein complex of parotid saliva is thought to form from saliva components which are secreted in a soluble form but which complex because the total calcium concentration exceeds a limiting amount. The secretion products filling the lumen of ducts in the human parotid gland as described by Riva and Riva-Testa (33) appear to be diluted zymogen granule material and undissolved spherules. The size of crystals and rapidity of formation indicate that ducts of glands could easily become blocked, particularly by complexes precipitating from sluggish unstimulated secretions. Since CF patients have elevated calcium levels in parotid saliva $(4,6)$, duct blockage $(20$. 35 ) and dental calculus formation (41) are more likely to occur in these subjects.

\section{SUMMARY}

The $2^{\circ}$ cold-dependent turbidity of parotid saliva of both CF patients and non-CF subjects consisted of colloidal aggregates of protein, whereas the $37^{\circ}$ calcium-dependent turbidity contained crystalline hydroxyapatite, unidentified crystals with cubic diffraction patterns, and amorphous material. The sparingly soluble proteins in the $2^{\circ}$ and $37^{\circ}$ pellets comprised proline-rich proteins and a calcium-precipitable, TCA-precipitable phosphoprotein, which fluoresced with amido schwarz and Coomassie brilliant blue G250.

\section{REFERENCES AND NOTES}

1. Allars. H. M., Blomfield, J.. Rush, A. R., and Brown, J. M.: Colloid and crystal formation in parotid saliva of cystic fibrosis patients and non-cystic fibrosis subjects. 1. Physicochemistry. Pediat. Res., 10: 578 (1976).

2. Azen, E. A.. and Oppenheim, F. G.: Genetic polymorphism of proline-rich human salivary proteins. Science, 180:1067 (1973).

3. Beevers, C. A.: The crystal structure of dicalcium phosphate dihydrate. $\mathrm{CaHPO}_{4} \cdot 2 \mathrm{H}_{2} \mathrm{O}$. Acta Crystal., H: 273 (1958).

4. Blomfield, J., Allars, H. M., Rush, A. R., van Lennep, E. W., and Brown. J. M. Parotid serous hypersecretion in cystic fibrosis. Aust. Paediat. J.. 10: 75 (1974).

5. Blomfield, J. Dascalu, J., van Lennep, E. W., and Brown, J. M.: Hypersecretion of zymogen granules in the pathogenesis of cystic fibrosis. Gut, 14: 558 (1973).

6. Blomfield, J., Rush, A. R., Allars, H. M.. and Brown. J. M.: Parotid gland function in children with cystic fibrosis and child control subjects. Pediat. Res., 10: 574 (1976).

7. Blomfield. J., van Lennep, E. W., Shorey, C. D., Malin. A. S.. Dascalu, J., and Brown, J. M.: Ultrastructure of the in vitro formation of hydroxyapatite in submandibular saliva of children with cystic fibrosis. Arch. Oral Biol.. 19: 1153 (1974).

8. Blomfield, J., Warton, K. L., and Brown, J. M.: Flow rate and inorganic components of submandibular saliva in cystic fibrosis. Arch. Dis. Childhood. 48: 267 (1973).

9. Boat, T.F. Wiesman, U. N., and Pallavicini, J.C.: Purification and properties of the calcium-precipitable protein in submaxillary saliva of normal and cystic fibrosis subjects. Pediat. Res., 8: 531 (1974).

10. Brown, W. E.. Lehr. J. R.. Smith. J. P., and Frazier, A. W.: Crystallography of octacalcium phosphate. Amer. Chem. Soc., 79: 5318 (1957).

11. Brown, W. E., Smith. J. P.. Lehr, J. R., and Frazier, A. W.: Crystallographic and chemical relations between octacalcium phosphate and hydroxyapalite. Nature, 196: $1050(1962)$.

12. Cancro, L. P.; Mones, E. Martin. D. M.. and Weaver, J. M.: The formation of hydroxyapatite during incubation of saliva. Abstract 234, p. 107 . International Association for Dental Research, 48th General Meeting. New York. 1970.

13. Davis, B. J.: Disc electrophoresis. II. Method and application to human serum proteins. Ann. N. Y. Acad. Sci., 12 I (2): 404 (1964).

14. Eanes, E. D.. Termine, J. D., and Nylen. M. V.: An electron microscopic study of the formation of amorphous calcium phosphate and its transformation to crystalline apatite. Calc. Tiss. Res., 12:143 (1973).

15. Francis, M. D., and Webb, N. C.: Hydroxyapatite formation from a hydrated calcium monohydrogen phosphate precursor. Calc. Tiss. Res., 6: 335 (1971).

16. Frondel, $\mathrm{C}$.: Whitlockite: A new calcium phosphate, $\mathrm{Ca}_{3}\left(\mathrm{PO}_{4}\right)_{2}$. Amer. Mineral. 26: 145 (1941)

17. Füredi-Milhofer, H.. Purgarić, B.. Brečević, L.. J., and Pavković, N.: Precipitation of calcium phosphates from electrolyte solutions. I. A study of precipitates in the physiological pH region. Calc. Tiss. Res., 8: 142 (1971).

18. Hay, D. I.: The interaction of human parotid salivary proteins with hydroxyapatite. Arch. Oral Biol., 18: 1517 (1973).

19. Hay. D. I.: The isolation from human parotid salival of a tyrosine-rich acidic peptide which exhibits high affinity for hydroxyapatite surfaces. Arch. Oral Biol. 18: 1531 (197.3).

20. Johansen. P. G., Anderson. C. M.. and Hadorn. B.: Cystic fibrosis of the pancreas: A generalized disturbance of water and electrolyte movement in exocrine tissues. Lancet, i: 455 (1968).

21. Kamiya, M. and Okuyama, $T$.: Staining of phosphoproteins on polyacrylamide gels with acridine orange. Seikagaku, 45: 327 (1973).

22. Karnovsky, M. J.: A formaldehyde-glutaraldehyde fixative of high osmalality for use in electron microscopy. J. Cell Biol., 27: 137^ (1965).

23. Larsen, S., and Widdowson. $\Lambda$. E.: Hydroxyapatite: Preparation and properties Experientia, 27: 483 (1971).

24. Leach, S. A.: Salivary products in plaque and saliva. J. Dent. Res.. 53: 310 (1974).

25. Mayo, J. W. and Carlson, D. M.: Protein composition of human submandibular secretions. Arch. Biochem. Biophys., 161: 134 (1974).

26. McKenzie, H. A.: Milk proteins. Advan. Protein Chem.. 22: 55 (1967).

27. Mever, J. L., Eick, J. D., Nancollas, G. H., and Johnson, L. N.: A scanning eieciron milioscopie study of the growth of hydroxyapatite crystals. Cale. Tiss. Res.. 10:91 (1972).

28. Noble, R. W., and Waugh. D. F.: Casein micelles: Formation and siructure. I. Amer. Chem. Soc. J., 87: 2236 (1965).

29. Nylen, M. U., Eanes, E. D., and Omnell, K.- .: Crystal growth in rat enamel. J Cell Biol. 18: 109 (1963)

30. Pallavicini, J. C.: Attachment for the Buchler apparatus for use with polyacrylamide gel electrophoresis. Reprinted by permission of Buchler Instruments. Inc., Fort Lee. N. J. (1964)

31. Posner, A. S.: Crystal chemistry of bone mineral. Physiol. Rev., 49: 760 (1969).

32. Reisner, A. H., Nemes, P., and Bucholt\%. C.: The use of Coomassie Brilliant Blue G250 to stain isoelectro-focused and gradient pore separated proteins in polyacrylamide gels. Anal. Biochem., 64: 509 (1975).

33. Riva, A., and Riva-Testa, F.: Fine structure of acinar cells of human parotid gland. Anat. Rec., 176: 149 (1973).

34. Schroeder. H. E.: Crystal morphology and gross structures of mineralizing plaque and of calculus. Helv. Odont. Acta, 9:73 (1965).

35. Shackleford, J. M., and Bentley, H. P.: Carbohydrate histochemistry of the salivary glands and pancreas in cystic fibrosis. J. Histochem. Cytochem., 12. $512(1964)$.

36. Steve-Bocciarelli, D.: Apatite microcrystals in bone and dentine. J. Microsc. I6 $21(1973)$ 
37. Termine. J. D., and Eanes. E. D.: Comparative chemistry of amorphous and apatitic calcium phosphate preparations. Calc. Tiss. Res., 10: 171 (1972).

38. Termine. J. D.. and Posner, A. S.: Calcium phosphate formation in vitro. 1 Factors affecting initial phase separation. Arch. Biochem. Biophys.. 140: 307 $(1970)$

39. Warton, K. L., and Blomfield. J.: Hydroxyapatite in the pathogenesis of eystic fibrosis. Brit. Med. J., 3: 570 (1971).

40. Waugh, D. F and Noble, R. W. Cascin micelles: Formation and structure. II J Amer. Chem. Soc. 87: 2246 (1965)

41. Wotman, S.. Mercadante. J.. Mandel. 1. D.. Goldman, R. S.. and Denning. C.: The occurrence of calculus in normal children. children with cystic fibrosis. and children with asthmat. J. Periodontol. 44: 278 (1973)

42. Young, R. A., and Filliott. J. C.: Atomic scale bases for several properties of apatites. Arch. Oral Biol.. 11: 699 (1966)
43. Polaron Equipment I.td., London

44. Data are from the American Society for Testing and Materials Powder Diffraction Files

45. Serva, Heidelberg.

46. Autopsy specimens were obtained through the cooperation of Dr. R. D. K. Reye and Dr. P. Bale of the Institute of Pathology, Royal Alexandra Hospital for Children, Camperdown.

47. This research was supported in part by The (ystic Fibrosis Association of Neu South Wales, The Clive and Vera Ramaciotti Foundations, and The Nattionil Health and Medical Research Council of Australia.

48. Requests for reprints should be addressed to: J. Blomfield. M.Sc., Children's Medical Research Foundation, P.O. Box 61. Camperdown. N.S.W. 2050 (Australia).

49. Accepted for publication December 18, 1975.
Bilirubin binding proteins bilirubin glucuronylt ransferase breast milk jaundice

\title{
Breast Milk Jaundice: In Vitro Inhibition of Rat Liver Bilirubin-Uridine Diphosphate Glucuronyltransferase Activity and $Z$ Protein-Bromosulfophthalein Binding by Human Breast Milk
}

\author{
A. FOLIOT:43: J. P. PLOUSSARD, E. HOUSSET, AND B. CHRISTOFOROV
}

Unité de Recherches de Biologie Animale et Techniques Expérimentales, INSERM, Paris, France

R. LUZ.EAU AND M. ODIEVRE

Unité d'Hépatologie Infantile, INSERM, Paris, France

\section{Extract}

Twenty-four samples of breast milk from nine mothers of infants suffering from breast milk jaundice were studied. Eight samples of milk from mothers of nonjaundiced infants, along with five formula milks enriched with polyunsaturated fatty acids, served as controls. Milks from mothers with jaundiced infants had no inhibitory effect when assayed immediately after thawing. However, after these milk samples were stored at $4^{\circ}$, they strongly inhibited bilirubin conjugation $(80.3 \%$ inhibition of uridine diphosphate glucuronyltransferase (UDPGT) activity) and bromosulfophthalein (BSP) binding to cytoplasmic $Z$ protein (dye binding inhibited $82.1 \%$ ). There was no effect on BSP binding to $Y$ protein (see Table 1). Heating the milk to $56^{\circ}$ modified the results in the following manner; when the milk was heated immediately after thawing, no inhibitory effect was seen, even after storage for $96 \mathrm{hr}$. On the other hand, when the milk was first stored at $96 \mathrm{hr}$ and then heated, it had the same inhibitory effects as the milks which were stored without heating. The present study shows that pathologic breast milk will inhibit BSP-Z protein binding only when stored under conditions that also cause the appearance of the capacity to inhibit bilirubin conjugation in vitro, as well as causing the liberation of nonesterified fatty acids. Thus, the appearance of this inhibitory capacity in vitro seems linked to the lipolytic activity particular to pathologic milks.

\section{Speculation}

By demonstrating that the in vitro inhibition of bilirubin conjugation by pathologic milks is due to the tying up of hepatic transport proteins, we have furnished the missing link in the sequence of events following ingestion of potentially inhibitory milk resulting in neonatal jaundice. We call the pediatrician's attention to the key role of ingested free fatty acids in the etiology of this condition.

A new variety of neonatal jaundice linked to maternal milk was reported nearly simultancously by Newman and (Gross (31) and by Arias et al. (4) and has since been confirmed by numerous authors $(19,22,27$ 29). Gartner and Arias (16, 17) attributed this hyperbilirubinemia to the transmission of a thermo-stable factor in breast milk from the mother to the child. They identified this factor as being $3 \alpha, 20 \beta$-pregnanediol, an isomer of a natural steroid, and further demonstrated that it was capable of inhibiting bilirubin conjugation in vitro as well as causing hyperbilirubinemia in normal infants. However, considerable doubt has been cast on this steroid's role in the etiology of this jaundice: its presence in milk considered "inhibitor" is not constant $(36,37)$ and its in vitro inhibitory effect on bilirubin conjugation is strongly contested ( 1 , $2,8,21,27)$, although it could have an inhibitory effect on the transport of conjugated bilirubin (2).

Recently, Levillain et al. (27) have established several facts: (I) in vitro inhibition of bilirubin conjugation is localized in the lipid fraction of inhibitory milks and (2) the ability to inhibit increases with storage time and is related to unusually high levels of free fatty acids, predominantly unsaturated. These inhibitory milks are further characterized by the ability to liberate normal fatty acids in large quantities, which is probably due to the presence of an abnormal or abnormally elevated thermolabile lipase activity. Shortly thereafter, Cole and Hargreaves (10) confirmed the role of storage time in inducing jaundice, whereas Bevan and Holton $(6,7$, 